\title{
ORGANIZACJE POLONIJNE I TOŻSAMOŚĆ NARODOWA POLACY W BOŚNI I HERCEGOWINIE (BIH)
}

\author{
EWA NOWICKA
}

\begin{abstract}
Polish organisations and national identity. Poles in Bosnia and Herzegovina today
The article is based on the anthropological fieldwork based on participant observation and interviews conducted in 2014 during Program „Sigma” Erasmus Mundus 2 in Tuzla, Lukavac, Sarayevo and Mostar. The interviewees were the members of the Polish minority in Bosnia and Herzegovina engaged in Polish cultural organisations. The study aimed at understanding various types of bonds with Poland as a state or the culture and even family histories, as presented in the interviews and the Polish minority behaviour. The author poses the question: why the intense development of Polish organisations flourished in the period of war in 1991-1995, in spite of the fact that the Polish emigration to Bosnia started in the second half of 19th century. Presently the organisations are fading and even disappearing. The author explores the manifestations of the Polish identity and national ties in Bosnia and presents a typology linking the particular types of Polish identity with the time and character of the Polish emigration.
\end{abstract}

Autor: Ewa Nowicka, Collegium Civitas, Plac Defilad 1,00-901 Warszawa, ewanowickarusek@gmail.com

Słowa kluczowe: Polacy na Bałkanach, mniejszości narodowe, Bośnia i Hercegowina, organizacje polonijne, tożsamość narodowa

Keywords: Poles in the Balkans, national minorities, Bosnia \& Herzegovina, Tha Polonia organizations, national identity

Balcanica Posnaniensia. Acta et studia, XXIII, Poznań 2016, Wydawnictwo Instytutu Historii UAM, pp. 135150, ISBN 978-83-65663-26-9, ISSN 0239-4278. Polish text with a summary in English.

doi.org/10.14746/bp.2016.23.9

WSTĘP

Według danych statystycznych z 2013 roku, Bośnia i Hercegowina (BiH) liczy ponad 3 i pół miliona mieszkańców ${ }^{1}$. Całościowa liczba ludności tego państwa jest przybliżona ze względu na problemy z przeprowadzeniem ogólnopaństwowego spisu ludności i jej migrację, głównie do krajów Europy Zachodniej. Państwo to było przez stulecia obszarem krzyżujących się wpływów historycznych, kulturowych i politycznych, co obecnie wyraża się w złożoności jego struktury społecznej i narodowościowej. Współczesna BiH funkcjonuje na podstawie porozumienia pokojowego,

\footnotetext{
${ }^{1}$ Polacy w Bośni - http://polacy-w-bosni.pl/ [dostęp: 12.12 2016].
} 
zawartego przez strony konfliktu zbrojnego z pierwszej połowy lat 90 . XX wieku Serbów, Chorwatów i Boszniaków (słowiańskojęzycznych Muzułmanów). Umowa pokojowa, wynegocjowana w Dayton w amerykańskim stanie Ohio przy udziale pośredników międzynarodowych, a podpisana w grudniu 1995 roku w Paryżu, zakończyła krwawą wojnę bośniacką. Układ zobowiązywał strony do zakończenia działań wojennych i wycofania swoich sił zbrojnych poza wyznaczone strefy zdemilitaryzowane. Na podstawie tego aktu ustalono zewnętrzne i wewnętrzne granice państwa, jego podział administracyjny, zarysy ustroju. Obecnie Bośnia i Hercegowina składa się z dwóch części: Republiki Serbskiej (49\% terytorium), Federacji Bośni i Hercegowiny ( $51 \%$ terytorium) oraz autonomicznego dystryktu Brčko, podległego bezpośrednio rządowi centralnemu. Obecna struktura państwa charakteryzuje się daleko idącą komplikacją, co jest ttumaczone koniecznością godzenia sprzecznych interesów poszczególnych grup etnicznych, religijnych oraz regionalnych.

W 2010 roku ratyfikowana została ustawa o ochronie języków etnicznych. Oprócz trzech głównych narodów, Serbów, Chorwatów i Boszniaków (czasem określanych jako Muzułmanie, przez wielkie M), państwo zamieszkuje siedemnaście społeczności uznawanych jako mniejszości narodowe, w myśl przepisów obowiązujących od 2003 roku. W trakcie badań prowadzonych na terenie BiH wielokrotnie spotykałam się z opiniami, że prawna ochrona mniejszości jest dalece niewystarczająca. Przede wszystkim panuje dezorientacja co do definicji praw mniejszości, instytucja zrzeszająca ich przedstawicieli, Rada Mniejszości Narodowych pracuje opieszale i stanowi raczej organ o charakterze symbolicznym (przedstawiciele mniejszości, reprezentowanych $\mathrm{w}$ tym organie spotykają się raz na dwa miesiące). Reprezentantem interesów polskiej społeczności w Radzie jest Dejan Piotrowski.

W Bośni i Hercegowinie oficjalnie funkcjonuje sześć organizacji polonijnych: trzy w Republice Serbskiej (w Banja Luce, Prnjavorze, Gradiszce) i trzy w Federacji BiH (Sarajewo, Mostar, Tuzla). Do stowarzyszeń polonijnych należą głównie osoby polskiego pochodzenia, których przodkowie, rodzice, dziadkowie, pradziadkowie, przyjechali do pracy w przemyśle lub na roli. Nawet ci, którzy mają pradziadków Polaków, zwykle potrafią odtworzyć genealogię swoich rodzin i są dumni z polskich przodków. Drugą grupę tworzą osoby narodowości polskiej, z polskim obywatelstwem, które w czasach jugosłowiańskich zawarły związek małżeński z obywatelami Jugosławii i postanowiły osiedlić się w Bośni. Potocznie określa się ich mianem „prawdziwych Polaków” (prava Poljakinia, pravi Poljacy) ${ }^{2}$.

Zgodnie z doniesieniami z ostatnich miesięcy 2016 roku, z mapy bośniackiej Polonii zniknęła stowarzyszenie z Tuzli. Zostało ono wyrejestrowane z powodu niedostatecznego zainteresowania oraz braku funduszy na działalnośćs. Stało się tak,

\footnotetext{
${ }^{2}$ Zapis fonetyczny na podstawie wywiadów.

${ }^{3}$ Liczba osób z polskim pochodzeniem zamieszkujących Tuzlę, Lukavac i okolice jest trudna do ustalenia. Wedle obliczeń miejscowej działaczki polonijnej Izabelli Andrić, w 2014 roku mieszkało tam blisko 300 osób. W samej Tuzli doliczyła się ona 75 osób pochodzenia polskiego i trzech Polek pozostających w związkach małżeńskich (dwa małżeństwa polsko-chorwackie i jedno polsko-boszniackie).
} 
choć właśnie w Tuzli i okolicach mieszka stosunkowo liczne środowisko polonijne. Właśnie tam, w pierwszej połowie lat dziewięćdziesiątych XX wieku zrodził się pomysł stworzenia prężnej organizacji, mającej zintegrować rozproszonych terytorialnie Polaków i potomków Polaków. Dodajmy, że wiele osób polskiego pochodzenia pracowało w Tuzli w kopalni soli i było zatrudnionych w miejscowym przemyśle, chociażby w Lukavcu, w zakładach chemicznych. Najczęściej Polacy zamieszkiwali też wioski o mieszanej strukturze etnicznej. Tak jest w okolicach Banja Luki lub miasteczka Prnjavor. Wśród przodków polskich imigrantów zdarzali się inteligenci - lekarze lub urzędnicy pracujący w administracji austrowęgierskiej na przełomie XIX i XX wieku. Z Tuzlą związane jest także wspomnienie działalności dr Teodory z Kosmowskich Krajewskiej (1854-1935). Przez kilkadziesiąt lat leczyła ona kobiety muzułmańskie, które $\mathrm{z}$ powodu surowych obyczajów religijnych nie mogły korzystać z publicznej opieki medycznej. Dodajmy, że postać Teodory Krajewskiej jest żywa wśród mieszkańców Tuzli, przed miejscowym szpitalem znajduje się poświęcony jej pomnik ${ }^{4}$.

\section{MATERIAŁ BADAWCZY I METODOLOGIA}

Niniejszy artykuł jest poświęcony osobom narodowości polskiej lub polskiego pochodzenia obecnie mieszkającym w BiH - ich postawom wobec własnej polskości oraz ich wizji przeszłości. Pierwszy rozważany problem badawczy wiąże się z pytaniem, dlaczego pomysł stworzenia organizacji polonijnej pojawił się dopiero $\mathrm{w}$ pierwszej połowie lat dziewięćdziesiątych XX wieku, w czasach konfliktu zbornego w Bośni. Kolejne pytanie dotyczy powodów słabnięcia więzi organizacyjnych w środowiskach Polaków i osób polskiego pochodzenia, żyjących w BiH. W tym celu scharakteryzuję ogólniejsze warunki społeczno-kulturowe, wpływające na losy inicjatyw podejmowanych przez przedstawicieli środowiska polonijnego. Określę sposoby kultywowania polskiej tożsamości narodowej w warunkach rozproszenia, małej liczebności i dużej mobilności demograficznej, a także złożonego środowiska etniczno-religijnego w BiH. W szczególności zajmę się charakterystyką tożsamości narodowej osób polskiego pochodzenia, które związały swoje życie z Bośnią po drugiej wojnie światowej. Dla zrozumienia wszystkich opisanych powyżej zjawisk, ważne jest przybliżenie społecznej charakterystyki polskiej zbiorowości w BiH, a także genezy poszczególnych środowisk, wchodzących w jej skład.

Artykuł powstał w oparciu o obserwację uczestniczącą i wywiady przeprowadzone w 2014 roku z przedstawicielami polskiej mniejszości w Tuzli, Lukavcu, Sarajewie oraz Mostarze, a więc na terenie Federacji Bośni i Hercegowiny, a także w miejscowości Prnjavor, która znajduje się w Republice Serbskiej. Najczęściej były to osoby zaangażowane organizacyjnie w działalność polonijną. Badanie miało cha-

\footnotetext{
${ }^{4}$ T. Krajewska, Pamiętnik, Kraków 1989.
} 
rakter studium antropologicznego, a najistotniejsze dla mnie było określenie, jakie rodzaje związków łączyły i łączą poszczególne osoby oraz grupy z Polską - krajem, kulturą, przeszłością i genealogią rodzinną. Biorąc pod uwagę ten kontekst zjawisk identyfikacyjnych, starałam się przedstawić proces tworzenia się i działalności organizacji polonijnych w BiH. Ich charakterystyka uwzględnia kontekst wydarzeń, które rozgrywały się w $\mathrm{BiH}$ w latach 90 . ubiegłego stulecia. Obecne są także odniesienia do współczesnych realiów społecznych, głównie na przykładzie Tuzli i satelitarnego miasta Lukavac, Sarajewa oraz Mostaru. Badania terenowe zostały przeprowadzone we wrześniu 2014 roku, w ramach stypendium Komisji Europejskiej Erasmus Mundus Akcja 2 - projekt Erasmus Mundus Akcja 2 SIGMA, koordynowanego przez Uniwersytet Warszawski ${ }^{5}$.

\section{ETAPY POLSKIEJ IMIGRACJI DO BOŚNI. LOSY POLSKICH IMIGRANTÓW}

Tradycja polskiej imigracji do Bośni sięga drugiej połowy XIX wieku. Jej poszczególne fazy można uporządkować następująco: okres austrowęgierski, okres Polski międzywojennej (1918-1939), czas drugiej wojny światowej na ziemiach jugosłowiańskich (1941-1945), okres jugosłowiański (1945-1991) i wreszcie postjugosłowiański, od 1991 roku.

Migracja w okresie austrowęgierskim (1878-1918)

W latach 1878-1918, gdy Bośnia znajdowała się pod władzą Habsburgów, dokonywała się tam intensywna modernizacja ${ }^{6}$. Zagospodarowywano nieużytki leśne, rozwijał się przemysł wydobywczy i chemiczny. W regionie, który ekonomicznie był zacofany, stopniowo kształtowała się nowoczesna infrastruktura. Polacy przybywali do Bośni jako osadnicy mający uprawiać ziemie rolnicze, lun jako pracownicy w burzliwie rozwijającym się przemyśle.

Migracja wiejsko-rolnicza w okresie austrowęgierskim (1878-1918)

Polska imigracja do Bośni w czasach austrowęgierskich przybrała znaczne rozmiary. Szacuje się ją na 20 tysięcy osób, głównie wychodźców z Galicji. Przybywali oni głównie na tereny leśne i zakładali gospodarstwa rolne. Proces osadniczy i kolo-

\footnotetext{
${ }^{5}$ Pełna nazwa: Critical Skills Learning for Innovation, Sustainable Growth, Mobility and Employ Ability in the Multicultural Environment of the Western Balkans. W skład konsorcjum wchodzi 10 uczelni bałkańskich i 9 uczelni unijnych. Strona internetowa projektu: www.sigma.uw.edu.pl.

${ }^{6}$ M. Rekść, Między pokojową koegzystencja a bratobójczymi walkami. Bośnia i Hercegowina jako egzemplifikacja społeczeństwa wielokulturowego, „Prace Naukowe Akademii im. Jana Długosza w Częstochowie. Res Politicae", 2009, t. 3, s. 163.
} 
nizacyjny dotyczył także i innych narodowości. I tak, wokół miejscowości Prnjavor (obecnie w Republice Serbskiej) powstało wiele wiosek zamieszkanych przez imigrantów pochodzących z różnych części wielonarodowego cesarstwa. Powstające tam na przełomie XIX i XX wieku wsie zwykle miały jednolity etnicznie charakter. Władze starały się oferować przybyszom atrakcyjne warunki osadnictwa. Rolnikosadnik dostawał około 10 hektarów lasu pod karczunek, co wielu imigrantów postrzegało jako szansę życiową ${ }^{7}$. Potomkowie imigrantów, moi rozmówcy z Tuzli i Lukavca mówili mi o dobrobycie polskich wsi, w porównaniu z zasiedlonymi przez Czechów, Rusinów, Ukraińców czy Włochów. Jak wspominają obecni potomkowie osadników, polskie gospodarstwa były bogate i ekspansywne ekonomicznie. Stabilna sytuacja materialna umożliwiała wzrost demograficzny i funkcjonowanie wielodzietnych rodzin. I tak, jak opisywał jeden $\mathrm{z}$ moich informatorów, brat jego matki miał dziewięcioro dzieci. Był on właścicielem tartaku i warsztatu stolarskiego, w których zatrudniał krewnych. Wszyscy osadnicy w wiosce, zamieszkanej przez jego rodzinę, mieli żywy inwentarz, krowy i konie oraz prowadzili dobrze prosperujące gospodarstwa rolne. W trakcie wywiadów rozmówcy odtwarzali genealogię rodzinną, opowiadając o losach przodków, z dumą pokazując zdjęcia rodzinne. I tak, dziadkowie jednego z rozmówców, Ignacy i Maria, przybyli do okolic Prnjavora w czasie pierwszej wojny światowej. Mieli siedmioro dzieci - czterech synów i trzy córki. Jedna z nich, matka rozmówcy, wyszła za mąż za katolika, zapewne Chorwata. Początkowo Polacy zostali osiedleni wraz z Czechami w małej wiosce Maczino Brdo koło Prnjavora, położonej daleko od miasta, bez udogodnień cywilizacyjnych. Z czasem rodzina przeniosła się do Prnjavora, gdzie życie było łatwiejsze. Podczas wywiadów wymieniano takie nazwiska osadników jak Minarski, Socha, Boczek, Boryna czy Pawłoski. Należy dodać, że w okolicy miasteczka istniało bardzo zróżnicowane środowisko etniczne, złożone z Polaków, Czechów, Ukraińców, Rosjan i Włochów. Na porządku dziennym były małżeństwa mieszane etnicznie, według moich rozmówców zwykle polsko-czeskie, rzadziej polsko-włoskie.

Rysowany w jasnych barwach obraz życia polskich osadników wiejskich w Bośni nie koresponduje ze wspomnieniami zebranymi od polskich reemigrantów na ziemie polskie, ani z informacjami przekazywanymi przez historiografię. Te wskazują, że los rolnika w Bośni był ciężki i wiele osób nie poradziło sobie z przeciwnościami. Imigranci otrzymywali ziemię, ale przez dziesięć lat nie wolno im było nią obracać, byli więc przypisani do jednego miejsca. Prawdopodobnie ta okoliczność spowodowała ograniczenie liczby wyjazdów do Bośni wśród polskiego chłopstwa, co obserwowano od 1905 roku$^{8}$. Dodajmy, że nie wszyscy przybysze otrzymywali ziemię, w dodatku wśród imigrantów sporo było osób, które nie miały doświadczenia w gospodarowaniu własną ziemią. Ci też najczęściej stosunkowo szybko wracali do rodzinnych stron. Decyzje o powrocie podejmowano także wskutek niekorzystnej po-

\footnotetext{
${ }^{7}$ M. Solecki, Utracony dom. Losy Polaków z Bośni, „Więź”, 2007, nr.10.

8 T. Bugaj, Reemigracja Ludności Polskiej z Jugosławii i jej osiedlenie na Dolnym Sląsku [19461947], „Rocznik Jeleniogórski”, 1982, R. 20, s.71.
} 
gody, i tak, na przełomie 1899 i 1900 roku Bośnię nawiedziła wyjątkowo ostra zima, nasilając proces reemigracji na ziemie polskie ${ }^{9}$. Według relacji reemigrantów, problemem były także stosunki z miejscową ludnością. Bardziej doświadczeni i pracowitsi polscy rolnicy szybciej się bogacili, wzbudzając zawiść, wręcz akty nienawiści ze strony rdzennych mieszkańców. Zgodnie z relacjami z różnych źródeł, ataki na osadników nasiliły się szczególnie podczas drugiej wojny światowej i tuż po jej zakończeniu. Można tylko domyślać się powodów dużej rozbieżności, występującej w obrazie życia polskich osadników w Bośni. Być może jest to związane z potrzebą usprawiedliwiania wyborów życiowych, których dokonały poszczególne osoby i rodziny, pozostając w Bośni lub wyjeżdżając z niej ${ }^{10}$.

W opowieściach dzisiejszych potomków imigrantów o historii rodzinnej pomijany jest także wątek powojennej reemigracji Polaków do Polski, która dotyczyła głównie okolic Bolesławca na Dolnym Śląsku. Nieobecność tematu reemigracji może mieć podłoże psychologiczne. Osoby, które nie wyjechały do Polski były najczęściej w związkach małżeńskich z rdzennymi mieszkańcami, głównie z Chorwatami i nie miały jednoznacznej motywacji, aby zmienić miejsce zamieszkania. $Z$ jeszcze większą siłą dotyczyło to dzieci pochodzących z tych małżeństw, które zwykle nie dostrzegają (bądź wypierają ze swojej świadomości) możliwości wyjazdu rodziny do Polski tuż po drugiej wojnie światowej, a także nie chcąc komentować wyborów swoich rodziców.

Osoby z polskim obywatelstwem, indagowane o powody pozostania w Bośni na początku lat 90 . XX wieku, mimo zagrożenia konfliktem zbrojnym, najczęściej tłumaczyły to względami osobistymi bądź rodzinnymi. Jedna z rozmówczyń, osoba wpływowa w środowisku polonijnym w BiH, nie zdecydowała się wyjechać do Polski, ponieważ była wówczas w zaawansowanej ciąży. Jak mówi, nie czuła też szczególnego zagrożenia, związanego z walkami zbrojnymi. Na miejscu pozostała także Polka, której małżonek, Jugosłowianin, postanowił jednak wyjechać do Polski w okresie największych walk. Kobieta opiekowała się córką. Z kolei jedna z mieszkanek Tuzli, zaangażowana w działalność organizacji polonijnej, która miała matkę polskiego pochodzenia i dobrze mówiła po polsku wyznała, że pojechałaby do Polski natychmiast, gdyby tylko pozwoliła jej na to sytuacja rodzinna. Swoją deklarację motywowała ona silnym sentymentem do polskiej kultury, a nie poczuciem zagrożenia, związanym $\mathrm{z}$ niestabilną sytuacją $\mathrm{w} \mathrm{BiH}$.

Bez wątpienia, zawierucha wojenna z lat 90 . XX wieku pogłębiła proces depopulacji Polonii bośniackiej, choć nie odbyło się to poprzez reemigrację. I tak, moi rozmówcy z okolic Prnjavora podkreślali, że w chwili obecnej we wsiach, które niegdyś były zamieszkane przez Polaków lub osoby polskiego pochodzenia, nie został nikt. Ludność przeniosła się do Chorwacji, wyemigrowała do Niemiec, Austrii, Włoch lub Kanady. W przypadku okolic Prnjavora wsie związane z tradycjami polskiej imigracji zostały zdominowane przez Serbów. Władze lokowały tam serbskich uchodźców z Chorwacji i Serbów przybyłych z innych części BiH. Jak stwierdził wnuk osadni-

\footnotetext{
${ }^{9}$ Ibidem, s.74-76.

${ }^{10}$ Ibidem, s.77-78.
} 
ków z czasów austrowęgierskich, dziś ludzie tam [do Prnjavora - E. N.] nie wracaja, bo $w$ dawnych miejscach zamieszkania nie ma pracy. Znamienne jest, że chwilę wcześniej opowiadał on, że jeszcze niedawno ludzie żyli tam bogato, mieli ziemię, dobytek i zwierzęta. Mój rozmówca, który zna rzeczywistość wiejską z opowiadań i własnych wokół nich fantazji, tłumaczył, że kiedyś ludzie na wsi mieli dużo dzieci i one zajmowaly się zwierzętami domowymi, a teraz ludzie maja mato dzieci, a zajmowanie się żywym inwentarzem zapewne nie jest pożądanym zajęciem.

Migracja miejsko-przemysłowa w okresie austrowęgierskim (1878-1918)

Udział Polaków w strukturach administracyjnych Bośni pod panowaniem habsburskim był znaczny. W Tuzli i Banja Luce, na stu urzędników sądowych co najmniej siedemdziesięciu legitymowało się polskim pochodzeniem, co więcej obrady trybunałów odbywały się tam w języku polskim. Polacy często pełnili funkcje starostów i w zasadzie byli dobrze przyjmowani przez miejscową ludność ${ }^{11}$. Polscy przybysze pojawili się także w Lukavcu, który od 1893 roku przeżywał intensywny rozwój przemysłowy. Zakładano tam nowoczesne fabryki chemiczne. Powstały wówczas ośrodek przemysłowy jest przedmiotem dumy dla mieszkających tam osób polskiego pochodzenia. Jak zapewniała emerytowana pracownica nadal czynnego zakładu, jej dziadek był tam zatrudniony jako specjalista, a fabryka produkowała sodę o najwyższej jakości w Europie. Według jej relacji, w tworzeniu tego zakładu uczestniczyli także polscy inżynierowie i eksperci, którzy licznie zasilali kadry kierownicze. W Lukavcu żywa jest pamięć o polskich specjalistach, jedna z tamtejszych ulic nosi nazwę od nazwiska jednego z ,ojców założycieli" przemysłowego centrum miasta - Petraka, krewnego mojej rozmówczyni. $Z$ drugiej strony, dużo jest informacji o polskich imigrantach, przybywających do Tuzli i Lukavca już pod koniec wieku XIX, wykonujących prace fizyczne. Babka jednej z informatorek przyjechała do Tuzli przed pierwszą wojną światową z Krakowa i pracowała jako kucharka. Jak z dumą podkreślała jej wnuczka, kobieta znała trzy języki, mówiła po niemiecku, polsku i chorwacku. Kolejne pokolenie zdobywało staranniejsze wykształcenie zawodowe. Ojciec informatorki ukończył szkołę techniczną w zawodzie tokarza, co uznawano za wyraz awansu społecznego. Co ciekawe, idealizacji uległa w narracjach moich rozmówców aparycja ich męskich przodków. W opowieściach są oni bardzo przystojni, wysocy i o jasnej cerze (najwyraźniej cenionej w bośniackich realiach). Właśnie tak miał prezentować się ,prawdziwy Polak” - pravy Poljak.

Ważnym momentem w rozwoju Lukavca i miejscowej społeczności polskiej było wybudowanie kościoła katolickiego oraz szkoły, która stała się ważnym ośrodkiem kulturalnym. Jeden $\mathrm{z}$ informatorów podkreśla, że w czasach przed pierwszą wojną światową nikt kto przyjechal, nie wyjeżdżał (...) zawierane byty matżeństwa i ludzie osiedlali się na stałe. Oznacza to, że miejsce było uznawane za perspektywiczne, stwarzało szansę na awans społeczny i ekonomiczny. W odczuciu moich rozmówców Polacy żyli tam w zgodzie z miejscową ludnością, gdyż byli podobni temperamental-

${ }^{11}$ Ibidem, s.70. 
nie i pod względem tradycji. Wspominają oni także emigrację polskiej kadry kierowniczej z Tuzli do Polski, wraz z odrodzeniem kraju w 1918 roku. Depopulacja polskiej ludności miejskiej i wiejskiej z rejonu Tuzli dopełniła się po zakończeniu drugiej wojny światowej, a dokładniej w latach 1945-1947, wraz z przeprowadzeniem akcji ,repatriacyjnej $^{12}$.

\section{MIGRACJE POLAKÓW Z I DO BOŚNI I HERCEGOWINY PO II WOJNIE ŚWIATOWEJ}

Jesienią 1945 roku do Bośni udała się Polska Misja Repatriacyjna z zadaniem zorganizowania przesiedleń ludności polskiego pochodzenia. Dnia 2 stycznia 1946 roku w Belgradzie podpisano w tej sprawie układ międzyrządowy. Pierwsze sto polskich rodzin przybyło do Bolesławca z Prnjavora w 1946 roku, w okresie od 2 marca do 5 listopada. Cztery składy pociągów pokonały trasę Bosanski Brod Okućany - Bolesławiec, przewożąc łącznie 15301 osób (2 930 rodzin). Transportowano również dobytek ruchomy reemigrantów, 1614 koni, 3578 sztuk bydła, 1808 świń i 220 owiec $^{13}$. W roku 1947 w okolicach Bolesławca osiedlono 54 rodziny. W Bośni zostali ci, którzy byli w związkach etnicznie mieszanych. Do tej pory w Tuzli, Lukavcu, a także mniejszych miejscowościach żyje już trzecie lub czwarte pokolenie, którego przedstawiciele mają odległych polskich przodków wśród dziadków lub pradziadków.

Z kolei przyjazdy z Polski do Jugosławii po drugiej wojnie światowej były powiązane $\mathrm{z}$ dwustronną współpracą gospodarczą lub międzypaństwowymi umowami edukacyjnymi. Należy wspomnieć o wyjazdach kontraktowych, ustalanych między przedsiębiorstwami nawet na dłuższe okresy. W tych ramach Polacy przez długie lata pracowali w przemyśle wydobywczym, obsługując np. w Tuzli specjalistyczny sprzęt kopalniany pochodzący z Polski. Polscy pracownicy kontraktowi, zatrudniani w kopalniach i innych zakładach przemysłowych, wyjechali z BiH na początku lat 90. XX wieku przed rozpoczęciem działań wojennych. Ich aktywność wpłynęła na ukształtowanie się zasadniczo pozytywnego odbioru Polaków w oczach społeczeństwa BiH. Na ogół jest on związany z osobą legitymującą się wysokim poziomem edukacji i szerzej - cywilizacji. Obrazu imigracji Polaków w okresie jugosłowiańskim dopełniają podróże w ramach stypendiów edukacyjnych i wymiany studenckiej. W tych przypadkach czasem dochodziło do zawierania związków małżeńskich, a międzynarodowa para musiała podjąć decyzję o miejscu zamieszkania. Ponieważ federacja jugosłowiańska była uznawana za kraj o większych niż Polska swobodach i dostępności dóbr, zwykle na nią padał wybór. Takich par małżeńskich, zwykle z żoną Polką i mężem Jugosłowianinem, można po kilka spotkać w każdym z trzech ośrodków miejskich, w których przeprowadziłam badania. Dodać należy, że dzieci tych par niejednokrotnie mieszkają w Polsce. Osoby te przeważnie mają polskie obywatelstwo i pełną kompetencję w zakresie znajomości kultury polskiej oraz języka polskiego.

\footnotetext{
12 Ibidem, s. 81, 87.

13 T. Bugaj, op. cit., s. 96.
} 
Spotkania skutkujące małżeństwem, związane z turystycznymi przyjazdami do Bośni i Hercegowiny stanowią najnowszą falę imigrantów z Polski. Zakładane w ten sposób rodziny mają tendencję do migracji między krajami małżonków. Takie osoby można spotkać także wśród działaczy polonijnych. I tak, przewodnicząca polskiego stowarzyszenia w Tuzli (działającego w okresie, gdy prowadziłam badania w 2014 r.) Izabella Andrić zamieszkała w Bośni w 1982 roku. Przewodnicząca polskiego towarzystwa kulturalnego w BiH Mieszko I, Regina Trbonja, przybyła do Mostaru po zawarciu małżeństwa w 1980 roku. Natomiast Irmina Ćengić ze stowarzyszenia polskiego w Sarajewie przyjechała tam z rodzicami w wieku 11 lat.

\section{OKOLICZNOŚCI POWSTANIA STOWARZYSZEŃ POLONIJNYCH W BIH KONTAKTY Z POLSKA}

Aktywizacja Polaków zamieszkujących BiH w kierunku tworzenia własnych stowarzyszeń przypadła dopiero na okres rozpadu socjalistycznej Jugosławii. Przewodnicząca organizacji polonijnej z Tuzli jako datę jej stworzenia wymienia rok 1995, gdy kończyła się wojna bośniacka i został zawarty układ pokojowy w Dayton. Stworzenie stowarzyszenia było możliwe dzięki starszym przedstawicielom miejscowej Polonii (Branka Iljić i Antoni Wróblewski), którzy dotarli do osób z polskimi korzeniami, początkowo tworząc tzw. bank adresów. We wspomnieniach innego aktywisty nieistniejącej już organizacji z Tuzli, powstała ona w początkowym okresie wojny w BiH. W jego opinii, ukonstytuowanie się stowarzyszenia było związane z planami zwrócenia się do polskich władz i opinii publicznej o wsparcie materialne dla Polonii. Według tej relacji, ludzie z tego powodu garnęli się do stowarzyszenia. Starania o własną reprezentację widać było wszędzie tam, gdzie mieszkały środowiska odwołujące się do polskości, w Sarajewie, Mostarze czy Banja Luce. Narzuca się pytanie, dlaczego ta aktywizacja organizacyjna Polaków przypadła właśnie na czas konfliktu bośniackiego? Wedle dość popularnej hipotezy, pamięć o przodkach i o korzeniach narodowych odrodziła się w tamtejszych społecznościach w następstwie zagrożenia wojennego. Osoby, które można uznać za liderów miejscowej Polonii, dość jednomyślnie odrzucają jednak tę interpretację. W Mostarze i Sarajewie spotkałam się z opinią, że inicjatywa zrzeszenia Polaków wyszła od polskiej ambasady. Jej realizacja była możliwa dzięki działaniom prowadzonym w latach 2005-2010 przez byłego ambasadora, generała Andrzeja Tyszkiewicza i konsula Krzysztofa Wojtyniaka. Jak stwierdziła założycielka polskiego stowarzyszenia w Mostarze Regina Trbonja, jego działalność polega na „pielęgnowaniu” kontaktów z polskością poprzez organizowanie spotkań, okazjonalnych zebrań i uroczystości, z uwzględnieniem akcentów kulturalnych i towarzyskich. Ponadto stowarzyszenie pośredniczy w propagowaniu wśród miejscowych Polaków stypendiów dla młodzieży, kolonii, kursów językowych i wycieczek turystyczno-krajoznawczych do Polski. Dużym wydarzeniem dla społeczności zamieszkującej Tuzlę i okolice była chociażby tygodniowa wycieczka do Krakowa i Wieliczki, zorganizowana w 2007 roku. Dla wielu osób stała się ona 
szansą na pierwszy bezpośredni kontakt z krajem przodków. Wyprawę sponsorowali polscy specjaliści od kopalnictwa, którzy w latach 2007-2009 pracowali w Tuzli na kontraktach. Miejscowi działacze podkreślają, że wspólna wycieczka do Polski wzmocniła więzi między członkami społeczności, którzy później chętniej włączali się do innych inicjatyw.

Według zgodnej opinii liderów środowisk polonijnych z Tuzli, Sarajewa i Mostaru, aktywność ich stowarzyszeń byłaby niemożliwa bez wsparcia materialnego ze strony władz polskich. Jak mantra we wszystkich wywiadach powtarzana jest konieczność stałej pomocy finansowej dla miejscowych środowisk polonijnych. Starsza rozmówczyni z Tuzli powiedziała wprost, że przyjazd do Tuzli i z powrotem [na zebranie polonijne lub organizowaną imprezę kulturalną - E.N.] już jest kosztowny, a dla niektórych jest to suma nie do opłacenia przy niskich emeryturach.

Pojawia się pytanie, w jakim stopniu działalność poszczególnych organizacji polonijnych miała charakter oddolny, a na ile były one organizowane pod wpływem przedstawicielstwa dyplomatycznego państwa polskiego. I tak, wśród rozmówców z Mostaru powtarzana jest opinia, że dopóki nie było inicjatywy ze strony władz polskich, dopóty żyjący tam Polacy nie utrzymywali ścisłych kontaktów między sobą. Jak stwierdziła przewodnicząca organizacji polonijnej z Sarajewa, za czasów Jugosławii nie było żadnych organizacji mniejszościowych, stowarzyszeń polskich, a ci, którym odpowiadało towarzystwo konkretnych osób, kontaktowali się z nimi [bezpośrednio: E.N.]. Dopiero za pośrednictwem ambasady RP w poszczególnych miejscowościach zaczęto organizować spotkania opłatkowe, tzw. mikołajki, a w Sarajewie celebrowano polskie święta narodowe z udziałem osób z miejscowości oddalonych od stolicy. Był to również okres ożywionej działalności stowarzyszenia w okolicach Tuzli, gdy jak opisują jego byli członkowie, organizowano spotkania z udziałem konsula polskiego i przedstawicieli ambasady. Centralnie położony, reprezentacyjny Hotel „Tuzla” służył jako miejsce okazjonalnych przyjęć w mieście, dokąd zjeżdżało się ponad 100 osób. Podobne relacje zawarte są w wywiadach z Mostaru i Sarajewa.

Kolejna hipoteza w sprawie źródeł swoistego „entuzjazmu organizacyjnego” Polonii w okresie konfliktu bośniackiego i tuż po jego zakończeniu wiąże się z przypuszczeniem, że poszczególne osoby szukały wsparcia materialnego w warunkach dezorganizacji jugosłowiańskich struktur społecznych i państwowych. Zgodnie z tą interpretacją, osoby polskiego pochodzenia chętniej angażowały się w działalność polonijną, oczekując w zamian wsparcia humanitarnego i instytucjonalnego ze strony Polski. Pomoc w postaci paczek, a także wyjazdów dzieci i dorosłych do Polski była dla Polonii bośniackiej atrakcyjna w latach 90. XX wieku, szybko jednak spowszedniała. W organizacjach polonijnych pozostali nieliczni, najbardziej zmotywowani działacze, najczęściej osoby starsze. Stworzyszenia borykają się z problemami finansowymi. W liście, który otrzymałam od Izabelli Andrić w grudniu 2015 roku czytam

muszę przyznać że nasza Polonia już nie działa. Oczywiście kilka osób się spotyka, ale latami nie mieliśmy żadnego wsparcia oraz środków finansowych - że po prostu umiera śmiercia naturalna. Od lat nie mamy swojej kancelarii, wszystko znajduje się w piwnicach u znajomych. Emeryci sa niezainteresowani, a osoby mlodsze próbują za wszelka cenę znaleźć pracę. 
W zasadzie wszyscy moi rozmówcy wskazywali, że jedynym sposobem ożywienia życia polonijnego w BiH jest jego finansowanie przez polski rząd.

Stosunki z Polską są podtrzymywane przez osoby polskiego pochodzenia w różnym stopniu. Wśród rozmówców byli tacy, jak pani Slavica, której matka, Polka przybyła do Bośni w pierwszej połowie XX wieku. Do niedawna jeździła ona regularnie do Polski, do rodziny, a w domu z matką rozmawiała wyłącznie po polsku. Na początku lat dwutysięcznych prowadziła w Siedlcach kilkutygodniowe kolonie dla dzieci polskiego pochodzenia z Bośni i Chorwacji. Przykład ten wydaje się jednak odosobniony. Większość potomków polskich imigrantów w BiH utrzymuje bardzo luźne związki z Polską. Aby to zmienić, kilka lat temu w Tuzli zorganizowane zostało Stowarzyszenie Obywateli Pochodzenia Polskiego. Pod jego auspicjami były organizowane wycieczki do Polski, np. w 1999 roku do Krakowa.

\section{FORMY TOŻSAMOŚCI POLAKÓW Z BIH}

Wieloetniczny charakter Bośni oraz dramatyczne wydarzenia lat 90. XX wieku odciskają silne piętno na treści i tonie wywiadów z przedstawicielami tamtejszej Polonii. Stałym elementem obrazu powstałego na podstawie rozmów jest podkreślany przez wszystkich moich rozmówców, Polaków i potomków Polaków, tolerancyjny stosunek do innych grup religijnych i narodowych. Badane osoby najczęściej wyjaśniały, że w następstwie upadku Jugosławii i wojny domowej szczególne znaczenie zyskały podziały o charakterze religijnym, które w ich mniemaniu w pewnym stopniu osłabiły identyfikację etniczną lub narodową. W wypowiedziach rozmówców z trzech miast, w których prowadziłam badania (Tuzla, Sarajewo, Mostar) uwagę zwraca akcentowanie tolerancji religijnej, jako postawy kluczowej w wieloreligijnej i wieloetnicznej przestrzeni społeczno-politycznej. Jest to warunek sine qua non utrzymania harmonii w ramach niewielkich, ale bardzo zróżnicowanych wewnętrznie społeczności. Przykładowo, choć rodziny o polskich korzeniach z Tuzli i okolic najczęściej są skoligacone z katolickimi Chorwatami, wśród członków "Stowarzyszenia Polskiego" z Tuzli są także osoby, które tworzą mieszane związki z muzułmanami.

Co ważne, poszczególne osoby uczestniczące w badaniach, dystansowały się wobec tożsamości narodowej najbliższych i odwołując do identyfikacji ze strukturami państwowymi. Na pytanie Pani mąż jest Serbem?, członkini jednego z polskich stowarzyszeń odpowiedziała jest katolikiem, po czym wyjaśniła, że w jej optyce wszyscy tam są Bośniakami (Bosancy), a więc obywatelami BiH. Możliwe, że określenie „Bośniak” zyskuje szczególnie ważne zabarwienie dla przedstawicieli nielicznej społeczności polskiej, która nie chce być utożsamiana z katolickimi Chorwatami.

Tożsamość narodową osób polskiego pochodzenia w BiH należy rozumieć poprzez odniesienie się do wielonarodowego charakteru społeczeństwa tego kraju. Świadomość trwania w realiach wieloetniczności znajduje odbicie we wspomnieniach badanych. Jak opisywał jeden z rozmówców, w okolicy Prnjavora, dokąd przybyli jego 
dziadowie i urodziła matka wszyscy tam byli, Czesi, Ukraińcy, Włosi... różni, i Polacy. Jego zdaniem, ludzie pobierali się, nie zwracając uwagi na pochodzenie narodowe a w czasach titowskiej Jugosławii narodowość była sprawą prywatną i nie była oceniana. Z żalem odniósł się on do obecnych realiów w $\mathrm{BiH}$, gdzie pierwszym pytaniem jest Kim jesteś?, czyli ,jakiej jesteś narodowości?”. Określając swoją przynależność narodową, mój rozmówca powiedział, po ojcu moge powiedzieć, że Chorwat, a po matce Polak. No to kim jestem?. W wielu zebranych przez mnie wypowiedziach osób starszych, jak i przedstawicieli młodego pokolenia uwagę zwraca nostalgia za czasami socjalistycznej Jugosławii. W opinii rozmówców, dawały one poczucie stabilizacji i możliwość ucieczki przed etykietowaniem za pomocą konfliktogennych kategorii narodowych. Wiele osób z małżeństw mieszanych, które nie chciały lub nie mogły identyfikować się z żadną z głównych grup narodowych, w czasach socjalistycznej federacji określało swoją tożsamość jako jugosłowiańską. Do tej pory niektórzy Polacy, choć nie ma już socjalistycznej Jugosławii, z sentymentem mówią o swej niegdysiejszej przynależności.

W badaniach nad odmianami polskiej tożsamości jako punkt wyjścia wyodrębniłam kategorię ,polskości rdzeniowej”, czyli tożsamość narodową uformowaną na terenie państwa polskiego. Formuła ta dotyczy „rdzenia” narodu polskiego, bez którego polskość grup peryferyjnych bądź żyjących w rozproszeniu i oddaleniu od kraju byłaby niemożliwa. Wśród najważniejszych elementów uwzględnianych w tej kategorii wymienia się takie kwestie, jak (według liczby wskazań) poczucie bycia Polakiem, znajomość języka polskiego, kultury i historii Polski, narodowość polską przynajmniej jednego rodzica, polskie obywatelstwo, kultywowanie polskich obyczajów, a następnie mieszkanie i urodzenie się w Polsce, zasługi dla kraju i wiarę katolicką. Opisywany powyżej sposób pojmowania polskości, czyli polskie samookreślenie narodowe/etniczne, należy do grupy zjawisk „długiego trwania”, które mogą ulegać zmianom tylko w dłuższych okresach czasu. Należy przypuszczać, że zjawiska etniczne powinniśmy rozważać właśnie w tym ujęciu, jako takie, które mogą ulec zmianie w perspektywie kilku pokoleń.

Gdy przyglądamy się wypowiedziom osób polskiego pochodzenia w Bośni, jedynie ci, którzy sami przybyli z Polski spełniają większość warunków określających „polskość rdzeniową”. Mają polską identyfikację narodową, znają język, historię i kulturę polską, urodzili się i wychowali w Polsce, mają rodziców Polaków i utożsamiają się z katolicyzmem. Należy jednak pamiętać, że zagadnienie polskości przedstawia się inaczej w sytuacji życia poza krajem. W trakcie badań nad tożsamością Polaków i osób polskiego pochodzenia żyjących na wschód od obecnej granicy Polski, wyróżniłam pięć typów tożsamości narodowej, nawiązujących do różnych warunków społecznych, politycznych i demograficznych ${ }^{14}$.

„Polskość w zagrożeniu” jest zauważana przede wszystkim na obszarze Litwy, gdzie od lat 90. XX wieku daje się zauważyć napór rozkwitającego nacjonalizmu li-

${ }^{14}$ E. Nowicka, Polacy czy cudzoziemcy? Polacy za wschodnia granica, Kraków 2000. 
tewskiego na tamtejszą społeczność polską. Akcentowanie polskości przyjmuje formę bardzo intensywną i tradycyjną, często jest manifestacyjne i emocjonalne.

„Polskość ograniczona” - to zjawisko można spotkać głównie na Białorusi, gdzie mamy do czynienia ze słabą, bliską zaniku świadomością etniczną białoruską. Również tam polska świadomość narodowa jest słaba, głównie ze względu na brak polskiego szkolnictwa w czasach radzieckich ${ }^{15}$.

„Polskość rezydualna” - tę formę tożsamości narodowej odnoszę do Polaków z Kazachstanu. Przez dziesięciolecia nie mogła rozwijać się tam polska kultura, ale pozostała świadomość pochodzenia, wyrażająca się w akcentowaniu polskich nazwisk, polskiej przeszłości i pochodzenia, zarówno w linii ojca, jak i matki.

„Polskość zakonserwowana” - swoisty skansen polskości, w istocie ostatnio przechodzącej proces głębokich przemian globalizacyjnych. Jest ona skostniała i charakterystyczna np. dla nadal istniejącej syberyjskiej wsi Wierszyna, położonej 170 kilometrów na północ od Irkucka, gdzie w odosobnieniu mieszkają potomkowie dobrowolnych imigrantów ekonomicznych polskiego pochodzenia.

„Polskość sentymentalna” jest obecna przede wszystkim na obszarze Syberii, gdzie w rozproszeniu żyją potomkowie Polaków - dawnych zesłańców lub dobrowolnych osadników. W tym przypadku stowarzyszanie się jest trudne ze względu na duże rozproszenie terytorialne.

Zastosowanie powyższych kategorii w odniesieniu do Polonii z BiH natrafia na pewne trudności. Przede wszystkim Polacy trafiali do Bośni najczęściej z własnej woli, indywidualnie. Była to zawsze jakaś forma emigracji, zwykle ekonomicznej, czasem organizowanej, grupowej, częściej związanej z rodzinnymi losami i indywidualnymi wyborami. W przypadku polskości zagrożonej, ograniczonej i rezydualnej wśród polskiej ludności za wschodnią granicą, większość znalazła się poza granicami państwa polskiegoalbo w wyniku zmiany granic, albo przymusowej deportacji. Polacy na Syberii są albo potomkami dobrowolnych migrantów, z rzadka też dobrze wykwalifikowanych pracowników, albo stanowią kolejne pokolenie potomków zesłańców. Zatem porównując polskość sentymentalną w wydaniu syberyjskim i bośniackim, trzeba mieć w pamięci, że w przypadku tej drugiej dawne i współczesne migracje były dobrowolne. Nie towarzyszyła im żadna procedura karna, deportacyjna czy przymusowe przesiedlenia. Zapewne polscy mieszkańcy wsi, takich jak te koło Prnjavora, czy Banja Luki, kontynuowali tradycje kulturowe i językowe w formach znanych z czasów galicyjskich ${ }^{16}$. Zakonserwowane chłopskie formy polskiej kultury i więzi narodowej trwały w Bośni zapewne do 1945 roku. Rozbicie ich integralności postępowało pod naciskiem przeobrażeń cywilizacyjnych i migracji. Po drugiej wojny światowej, rozproszone terytorialnie ośrodki polskiego osadnictwa w Bośni zosta-

15 I. Kabzińska, Wśród „,kościelnych Polaków”. Wyznaczniki tożsamości etnicznej (narodowej) Polaków na Białorusi, Warszawa 1999.

${ }^{16}$ E. Nowicka, Wierszyna, czyli z morza na ocean, w: Słowiańskie Wyspy Językowe I Kulturowe, red. E. Nowicka, M. Głuszkowski, Toruń 2013, s. 13-27; E. Nowicka, Antropologiczny opis czy antropologiczna wizja, ,Przegląd Polonijny”, 2004, R. 1, s. 5-27. 
ły dodatkowo osłabione wskutek wyjazdu sporej części ludności do Polski, w trakcie planowej reemigracji.

Wraz z upływem czasu, w kolejnych pokoleniach, z reguły u potomków małżeństw narodowo mieszanych następowało odejście od znajomości języka, a polskość w tych następnych pokoleniach przybrała formę, którą, w odniesieniu do potomków Polaków żyjących na Syberii nazwałam ,polskością sentymentalną"17. Warunki pojawiania się i trwania tego rodzaju świadomości są związane z kilkoma okolicznościami. Zwykle świadomość sentymentalna jest tym bardziej intensywna, im lepszy jest stereotyp narodowości przybyszów w społeczeństwie osiedlenia. Sprawdza się to w przypadku osób polskiego pochodzenia w Bośni, gdzie obraz Polski i Polaków należy uznać za pozytywny, wpływający na akceptację własnego pochodzenia etnicznego. Zachowywaniu pamięci polskiego pochodzenia sprzyja także możliwość posiadania podwójnego obywatelstwa (bośniacko-chorwackiego, bośniacko-polskiego). Na moje pytanie o możliwość przeniesienia się do Polski, różne osoby podczas wywiadu odpowiadają rozmaicie. Te, które mają pochodzenie odległe w ogóle nie biorą takiego rozwiązania pod uwagę.

Należy zaznaczyć, że osoby polskiego pochodzenia, żyjące w Bośni w czasach po drugiej wojnie światowej, nigdy nie tworzyły grupy w sensie socjologicznym. Nie utrzymywały ścisłych kontaktów i nie miały wewnętrznej więzi na skalę całej BiH. Styczności i znajomości między osobami polskiego pochodzenia pojawiały się okresowo i miały indywidualny charakter. Będąc odcięci od kultury polskiej jako grupa, kultywowali ją indywidualnie. Nie są oni Polakami w odczuciu swoim i w odczuciu innych, ale jednocześnie mają świadomość polskiego pochodzenia, podkreślają je, co więcej nierzadko przez innych przedstawiani jako potomkowie Polaków. Odczuwalna jest wśród nich więź z polskimi symbolami.

\section{PODSUMOWANIE}

Wśród sytuacji, z którymi miałam okazję zetknąć się w Bośni, polskość przybiera albo formę rdzeniową, albo formę sentymentalną. Ta pierwsza forma dotyczy osób narodowości polskiej, które z Polski osobiście przybyły i spełniają wszystkie wyżej wskazane kryteria polskości z wyjątkiem mieszkania na stałe w Polsce. Znają polski język, kulturę, tradycję, obyczajowość, mają po stronie matki i ojca polskie pochodzenie, są katolikami, (co w BiH jest istotnym kryterium klasyfikacji etnicznych). Osoby, które tu przyjechały w wieku dorosłym, polskość zachowują w pełni, znajomość języka przekazując dzieciom, a nawet niepolskim narodowościowo współmałżonkom i utrzymując stały kontakt z Polską.

${ }^{17}$ E. Nowicka, Mnogolikost' polskoj idienticznosti. Poliacy za wostocznoj granicej, „Diaspory”, 2005, nr 4, s. 6-24. 
W przypadku Polaków reprezentujących tożsamość rdzeniową, kontakt z Polską i polską kulturą odbywa się na podstawie więzi rodzinnych i przyjacielskich. W przypadku potomków Polaków, charakteryzujących się polską tożsamością sentymentalną, jest to kontakt zapośredniczony przez działalność organizacji polonijnych.

Przyglądając się wypowiedziom działaczy stowarzyszeń polonijnych w BiH, natrafiamy na elementy różnych wskazanych wcześniej kryteriów polskości. Część badanych legitymowała się polskim obywatelstwem, są to przybysze z Polski z ostatnich dziesięcioleci. Ich dzieci też mają zwykle obywatelstwo polskie. Z kolei osoby urodzone w Jugosławii, które miały jedno z rodziców narodowości polskiej, raczej nie starały ani nie starają się o polskie obywatelstwa. Są to najczęściej osoby starsze, których przynajmniej jedno z rodziców urodziło się w Bośni przed wybuchem drugiej wojny światowej. Materiał zebrany podczas badań terenowych wskazuje jednak, że organizacje polonijne na terenie $\mathrm{BiH}$ trwają w oparciu o inicjatywę i wsparcie ze strony władz Rzeczpospolitej Polskiej. Rozproszenie terytorialne, mała liczebność, różnorodność indywidualnych losów sprawiają, że zbiorowość osób polskiego pochodzenia i etnicznych Polaków nie buduje więzi w oparciu o ten aspekt własnej biografii. Równocześnie w rozmowach z potomkami polskich osadników obraz przeszłości rodzinnej i wizerunek polskiej emigracji w Bośni ulega idealizacji.

\section{BIBLIOGRAFIA}

\section{Prace cytowane}

Bugaj Tadeusz, Reemigracja ludności polskiej z Jugosławii i jej osiedlenie na Dolnym Ślasku. 1946-1947, „Rocznik Jeleniogórski”, 1982, R. 20, s. 63-91

Bugaj Tadeusz, Reemigracja Ludnosci Polskiej z Jugosławii i jej osiedlenie na Dolnym Slasku[19461947], „Rocznik Jeleniogórski”, 1983, R. 21, s. 83-127.

Kabzińska, Iwona. Wśród „kościelnych Polaków”. Wyznaczniki tożsamości etnicznej (narodowej) Polaków na Białorusi, Warszawa 1999.

Krajewska Teodora, Pamiętnik, Kraków 1989.

Nowicka Ewa (red.), Swoi i obcy, Warszawa 1990.

Nowicka Ewa, Polacy czy cudzoziemcy? Polacy za wschodnia granica, Kraków 2000.

Nowicka Ewa, Łodziński Sławomir, U progu otwartego świata: poczucie polskości i nastawienia Polaków wobec cudzoziemców w latach 1988-1998, Kraków 2001.

Nowicka Ewa, Mnogolikost' polskoj idienticznosti. Poliacy za wostocznoj granicej, „Diaspory”, 2005, nr 4, s. 6-24.

Nowicka Ewa, Wierszyna, czyli z morza na ocean, w: Stowiańskie Wyspy Językowe I Kulturowe, red. Nowicka-Rusek Ewa, Głuszkowski Michał, Torun 2013, s. 13-27.

Polacy w Bośni - http://polacy-w-bosni.pl/ [dostęp: 12.12 2016].

Solecki Mariusz, Utracony dom. Losy Polaków z Bośni, „Więź”, 2007, nr 10.

Rekść Magdalena, Między pokojową koegzystencją a bratobójczymi walkami. Bośnia i Hercegowina jako egzemplifikacja społeczeństwa wielokulturowego, „Prace Naukowe Akademii im. Jana Długosza w Częstochowie. Res Politicae", 2009, t. 3, s.157-173

\section{Bibliografia dodatkowa}

Bachmiński Janusz, Bolesławiec, Wrocław 2000.

Buczek Czesław ,Reemigranci z Jugosławii na Ziemi Bolesławickiej, „Rocznik Dolnośląski”, 1982, nr 8. 
Bugaj Tadeusz, Reemigracja ludności polskiej z Jugosławii i jej osiedlenie się na Dolnym Ślasku 19461947, „Rocznik Jeleniogórski”, 1982, R. 20.

Bugaj Tadeusz, Matwijowski Krystyn, Bolesławiec - zarys monografii miasta, Wrocław- Bolesławiec 2001.

Burszta Józef, Kultura ludowa- kultura narodowa, Warszawa 1974, s. 125-127.

Drljaca Dusan, Między Bośnia, Bukowina, Serbia i Polska, Wrocław 1997.

Drljaca Dusan, Kwaśniewski Krzysztof, Drogi powrotu, „Odra”, 1961, R. 1, nr 7.

Jurgowski Tadeusz, Osiedlenie się Polaków z Jugosławii na ziemiach powiatu bolesławickiego, /maszynopis/.

Kaperski B., Z Bośni do Bolestawca, „Za Wolność i Lud”, 1972, nr 24.

Kwaśniewski Krzysztof, Z badań nad kultura ludowa reemigrantów polskich z Bośni, „Zeszyty Etnograficzne Muzeum Etnograficznego, Oddział Muzeum Śląskiego we Wrocławiu”, 1963, R. 1.

Mączka M., Ludzie odzyskani, „Świat i Polska”, 1947, R. 2, nr 21.

Okołowicz Józef, Wychodźstwo i osadnictwo w Polsce przed I Wojna Światowa, Warszawa 1927.

Polacy w Bośni, „Tygodnik Ilustrowany”, 1911, R. 2, nr 52.

Polacy z Jugostawii w Bolestawcu, „Repatriant”, 1947, R. 3, nr 10. 